\title{
Mortality of Children Under Five and Prevalence of Newborn Congenital Anomalies in Relation to Macroeconomic and Socioeconomic Factors in Latvia
}

\author{
Inguna Ebela ${ }^{1}$, Irisa Zile ${ }^{2}$, Aleksandrs Zakis ${ }^{1}$, Valdis Folkmanis ${ }^{1}$, Ingrida Rumba-Rozenfelde ${ }^{1}$ \\ ${ }^{1}$ Department of Paediatrics, Faculty of Medicine, University of Latvia, Riga, Latvia, \\ ${ }^{2}$ Centre of Health Economics, Riga, Latvia
}

Key words: mortality of children under five; infant mortality; macroeconomic factors; congenital anomalies; correlation.

Summary. Background. Mortality of infants and children younger than 5 years is a globally recognized and broad national welfare indicator. Scientific literature has data on the correlation of mortality indicators with macroeconomic indicators. It is important to study the associations between prevalence and mortality indicators and socioeconomic factors, since deaths from congenital anomalies account for approximately 25\%-30\% of all deaths in infancy. The aim of the study was to analyze the overall trend in mortality of infants and young children aged 0 to 4 years in relation to macroeconomic factors in Latvia and prevalence of congenital anomalies in newborns in relation to socioeconomic factors.

Material and Methods. The Newborns' Register and Causes of Death Register were used as data sources; data on specific socioeconomic factors were retrieved from the Central Statistics Office.

Results. The results of the study show a strong correlation between mortality in children younger than 5 years and gross domestic product, as well as health budget in LVL per capita and the national unemployment level. The average decrease in infant mortality from congenital anomalies in Latvia was found to be 6.8 cases per 100000 live births.

Conclusions. There is a strong correlation between child mortality and socioeconomic situation in the country. There is a need to analyze the data on child mortality in a transnational context on a regular basis and studying the correlations between child mortality indicators and socioeconomic indicators and health care management parameters.

\section{Introduction}

Scientific literature has data on the relationship between mortality indicators and gross domestic product (GDP) per capita, national health budget per capita, accessibility of health care, income share ratio in the bottom and top quintile, overall educational level, etc. $(1,2)$.

The World Health Organization (WHO) has divided the world in 6 regions based on child mortality rates. From a global perspective, Latvia belongs to the region of industrially developed countries with low child mortality rates; however, within the European region, Latvia has one of the highest child mortality rates and the highest child mortality rate in the Baltic States $(3,4)$.

When looking for solution to reduce infant and child mortality, there is a need to compare differences in the mortality structure in the Baltic States and in EU, as well as the factors that cause child mortality. In Latvia, a variety of perinatal conditions rank first in the infant mortality structure, whereas congenital anomalies rank second (5).

Correspondence to I. Ebela, Meža avenue 99, 2010 Jurmala, Latvia. E-mail: inguna.ebela@inbox.lv
In the developed countries, deaths from congenital anomalies and genetic impairment account for about $25 \%$ of all deaths in children younger than one year (6). Differences have been observed in the prevalence of congenital pathology in different population groups with relation to the assessed socioeconomic situation. Though various studies of this aspect are available in literature, the study data are difficult to compare and are contradictory, because of the different parameters for describing the socioeconomic situation, which may affect the expected result (7-9).

The aim of the study was to analyze the overall trends in mortality of children younger than 5 years in relation to macroeconomic factors in Latvia and prevalence of congenital anomalies in newborns in relation to socioeconomic factors, as well as to compare infant mortality indicators across the Baltic States.

\section{Material and Methods}

A correlational study was conducted. Time series datasets (1996-2007, each year regarded as one observation) were used to determine the associations between under-five child mortality (aged $0-4$ years) 
and macroeconomic indicators: GDP, health budget (HB), and unemployment. The time series datasets covered a period of 12 years. The strength of an association was described by the correlation/regression coefficient: $r$ ranging from 0 to 0.19 indicates very weak correlation; from 0.2 to 0.39 , weak correlation; from 0.4 to 0.59 , medium correlation; from 0.6 to 0.79 , strong correlation; and from 0.8 to 1 , very strong correlation.

The regression coefficient falls between -1 and 1 ; a positive sign indicates a positive correlation, and a negative sign indicates a negative correlation between the variables, while a value of 0 indicates that the specific factors are not correlated (10).

Data on mortality were retrieved from the Causes of Death in Latvia Database, and information on socioeconomic factors was collected from the database of the Central Statistics Office; mortality data from all the Baltic States were gathered from the World Health Organization database (Health for All, HFA).

Correlation/regression analysis was employed to establish the interrelations between pairs of factors. The horizontal axis (x-axis) of the regression equation was used for plotting the factorial feature (economic indicators), whereas the dependent variable (child mortality of a specific age group) was plotted on the vertical axis (y-axis). When analyzing the correlations, it was taken into account that the two variables were not necessarily related in a causeand-effect relationship.

Data on the prevalence of congenital anomalies were retrieved from the Newborns' Register database. The data analyzed with respect to congenital anomalies concerned live births recorded at various birth institutions for one or several anomalies in the period between 2000 and 2009 across Latvia.

For the purpose of the study, the dataset was subdivided into two principal groups according to maternal residence area (urban or rural according to the classifier of administrative territorial division), and the data were analyzed separately. The mothers of newborns were stratified by educational level into 5 groups: no primary education, primary education, secondary education, secondary vocational education, and higher education.

The period prevalence indicator and separate prevalence indicators according to summary diagnostic codes for congenital anomalies in the International Classification of Diseases (ICD-10) were calculated per 1000 live births for the period between 2000 and 2009 according to maternal residence area.

SPPS software version 15 was used for statistical processing of the data. The techniques of descrip- tive and analytical statistics applied were frequency distribution, cross tabulation, linear regression, and odds ratio (OR) calculation. The $\chi^{2}$ test was employed to establish differences between categorical variables. Differences were significant when $P$ value was less than 0.05 .

\section{Results}

Child Mortality in Latvia and Gross Domestic Product. Fig. 1 shows a very strong and significant correlation between GDP per capita in actual prices and mortality in children younger than 5 years $\left(R^{2}=0.6771, r=-0.822, P<0.001\right)$. Each $1 \mathrm{LVL}$ increase in GDP per capita was found to be associated with a decrease in mortality among children younger than 5 years by 0.0002 per 1000 children in the respective age group (Fig. 1).

Statistical data indicate only a very weak and not significant correlation between GDP per capita in average prices of year 2000 and mortality in children younger than 5 years $\left(R^{2}=0.0522, r=-0.228\right.$, $P>0.05)$ (Fig. 2).

Under-Five Mortality in Latvia and Health Budget. Fig. 3 shows a strong and significant correlation between health care expenditures in LVL per capita and mortality in children younger than 5 years $\left(R^{2}=0.5471, r=-0.739, P<0.05\right)$. A 1 LVL increase in health care expenditures per capita was associated a decrease in mortality of children younger 5 years by 0.0063 per 1000 children in the respective age group.

Child Mortality in Latvia and Unemployment. Fig. 4 shows a strong and significant correlation between unemployment and mortality in children younger than 5 years $\left(R^{2}=0.7181, r=0.8474, P<0.001\right)$. A $1 \%$ increase in unemployment was associated with an increase in mortality of children younger than 5 years by 0.0926 per 1000 children in the respective age group.

Comparison of Infant Mortality Across the Baltic States, Infant Mortality From Congenital Anomalies and Prevalence of Congenital Anomalies in Relation to Socioeconomic Factors in Latvia. Although infant mortality in Latvia has decreased from 13.7 per 100000 live births in 1990 to 7.7 per 100000 live births in 2009 (Fig. 5.), Latvia has the highest mortality rate across the Baltic States. The corresponding numbers for Estonia and Lithuania were from 12.3 and 10.3 per 100000 live births in 1990 to 3.6 and 5.0 per 100000 in 2009, respectively.

Analysis of the regression equations (Fig. 6.) on infant mortality from congenital anomalies showed that a decrease was more rapid in Latvia than other EU countries; however, mortality indicators in Latvia were several times greater than the average 


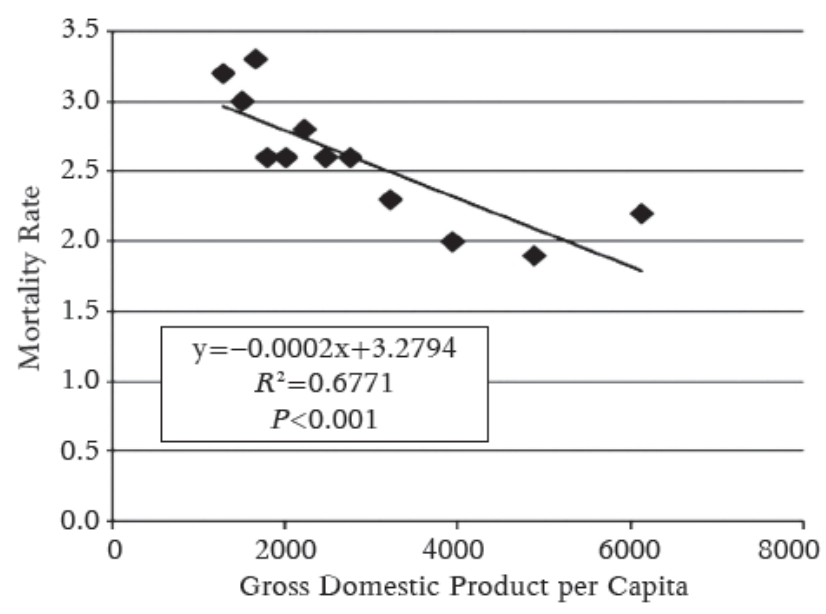

Fig. 1. Correlation between gross domestic product per capita in actual prices and under-five child mortality per 1000 live births

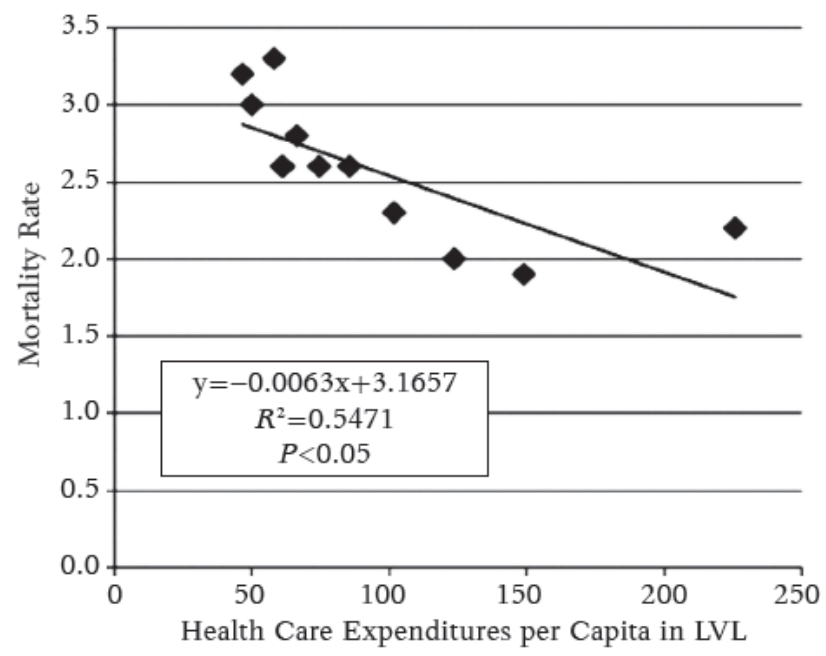

Fig. 3. Correlation between health care expenditures per capita in LVL and under-five child mortality per 1000 live births

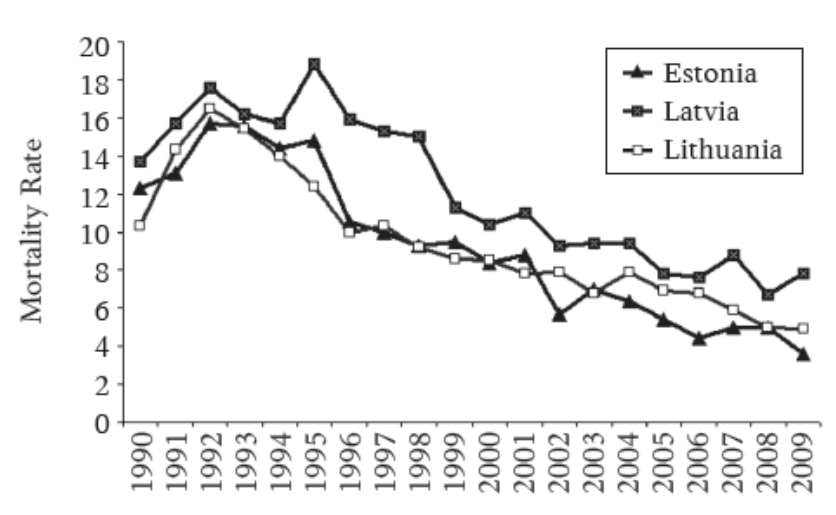

Fig. 5. Infant mortality rates per 1000 live births in the Baltic States during 1990-2009

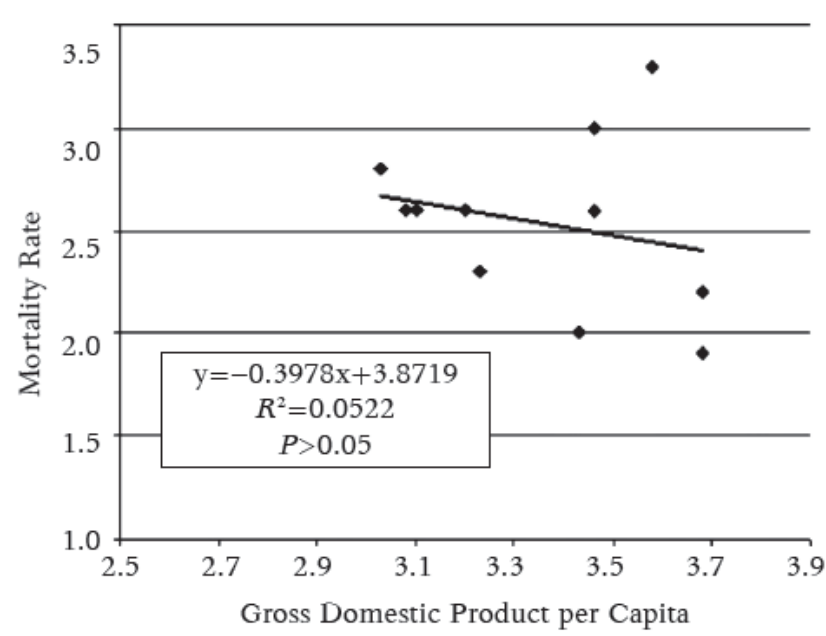

Fig. 2. Correlation between gross domestic product per capita in average prices and under-five child mortality per 1000 live births in 2000

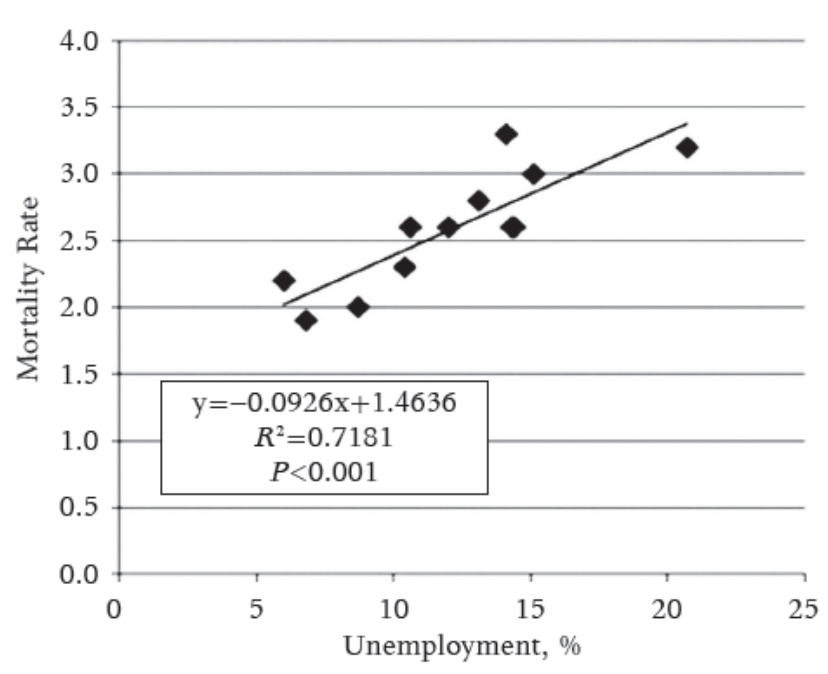

Fig. 4. Correlation between unemployment and under-five child mortality per 1000 live births

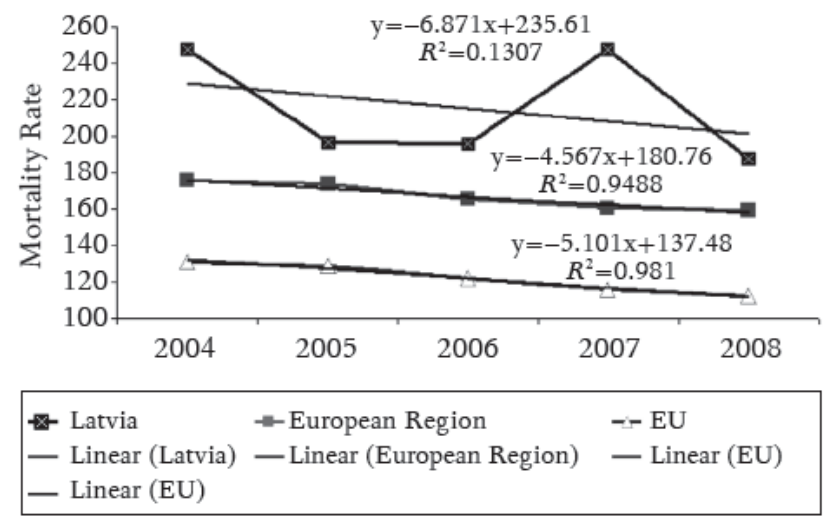

Fig. 6. Infant mortality rates from congenital anomalies (Q00-Q99) per 100000 live births during 2004-2008 
European indicators. In Latvia, the average annual decrease in infant mortality from congenital anomalies was 6.8 cases per 100000 live births.

Analysis of congenital anomaly rates in newborns during 2000-2009 showed that congenital anomaly rate was higher in urban than rural areas (29.29 per 1000 live births [95\% CI, 28.27-30.35] and 23.49 per 1000 live births [95\% CI 22.59-24.40], respectively); however, the difference was not significant.

Deformations of the musculoskeletal system (Q65-Q79) were the most frequently documented defects at birth in urban areas (8.97 per 1000 live births; 95\% CI, 8.41-9.56) and rural areas (7.24 per 1000 live births; 95\% CI, 6.75-7.76). Congenital malformations of the circulatory system (Q20Q28) ranked second: 7.63 per 1000 live births (95\% CI 7.12-8.18) in urban areas and 5.08 per 1000 live births (95\% CI 4.67-5.08) in rural areas. In urban areas, the third most common type of congenital anomalies was anomalies of the urinary system (Q60-Q64) (3.1 per 1000 live births; 95\% CI, 2.79-3.47), whereas in rural areas, other congenital malformations (Q80-Q89; congenital malformations of the skin, breast; congenital malformation syndromes involving several systems, etc.) (2.65 per 1000 live births; 95\% CI 2.36-2.97) (Fig. 7.)

Analysis of the urban/rural area differences in congenital anomalies in newborns with regard to maternal education revealed that the share of such congenital anomalies was higher among mothers with a lower education level (i.e., primary, secondary and secondary vocational) in rural areas than urban areas. The overall differences in newborns with congenital anomalies with regard to the level of maternal education were seen as statistically significant $\left(\chi^{2}=262.75 ; P<0.001\right)$.

Analysis of ORs for newborns with congenital anomalies by diagnostic category showed that for all diagnostic categories, the ORs for newborns were different if the mother resided in the rural area or in the urban area (Table), even though statistically significant OR indicators were observed only in 4 groups of pathologies.

Mothers residing in rural areas were more likely to have a newborn with cleft lip and cleft palate and other congenital anomalies (congenital skin, breast malformations, congenital malformation syndromes involving several systems, etc.) than those residing in urban areas (OR, 1.54; 95\% CI, 1.17-2.03; $\chi^{2}=10.07$, and OR, $1.39 ; 95 \%$ CI, $1.16-1.67 ; \chi^{2}=13.48$, respectively). However, mothers residing in rural areas were at lower risk to have a newborn with congenital malformations of the circulatory system (OR, 0.78; 95\% CI, 0.69-0.89; $\left.\chi^{2}=15.07\right)$ and deformities of the urinary system (OR, 0.59; 95\% CI, 0.48-0.72; $\chi^{2}=29.10$ ).

Mothers with lower education level residing in rural areas were at higher risk to have a newborn with congenital malformations and deformations of the musculoskeletal system (OR, 1.30; 95\% CI, $1.1-1.5)$.

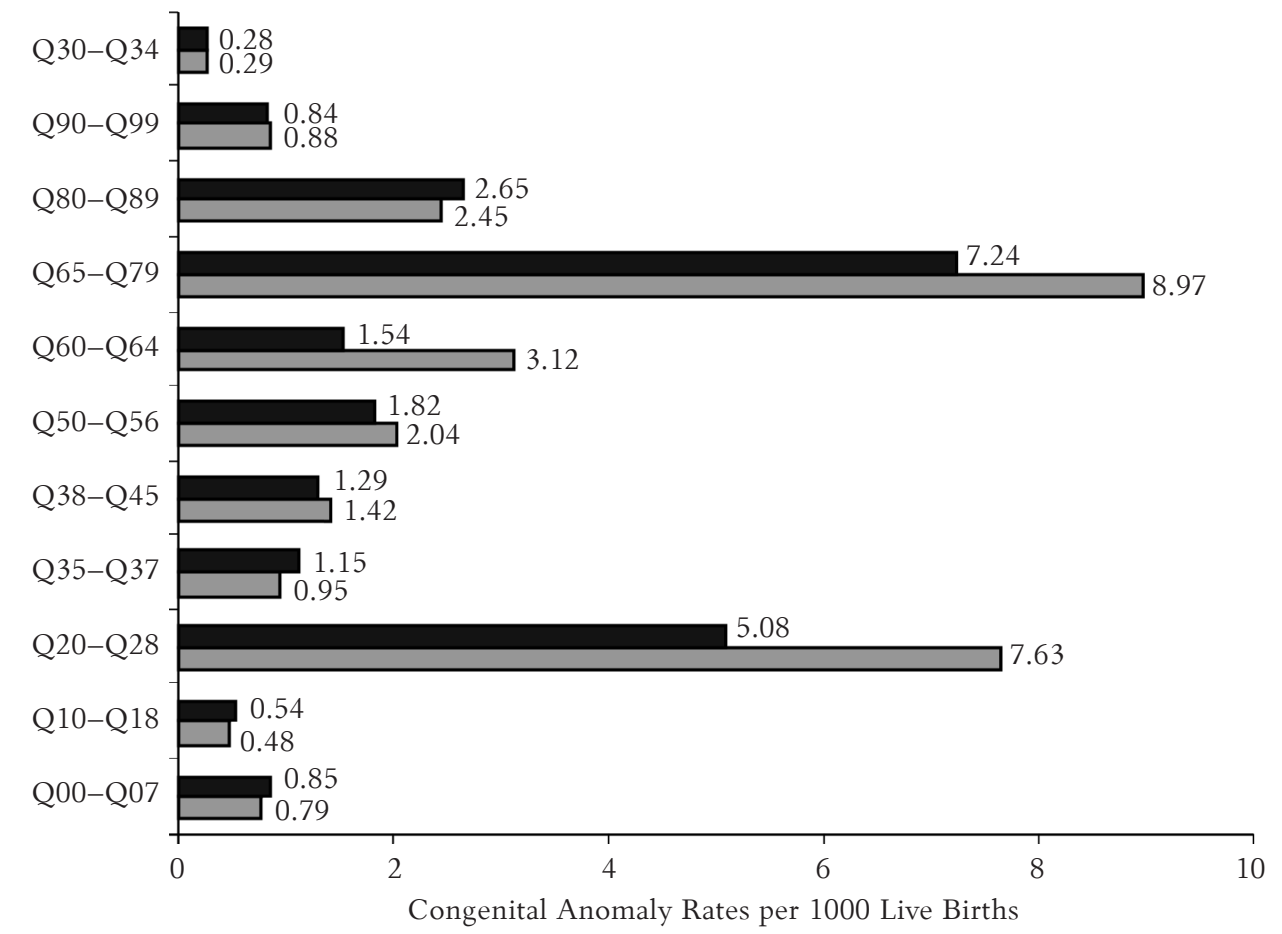

Fig. 7. Congenital anomaly rates per 1000 live births in newborns by maternal residence area during 2000-2009 
Table. Association between congenital anomalies and maternal residence place (reference category, live in cities)

\begin{tabular}{|c|c|c|}
\hline Diagnostic category of congenital anomalies (ICD-10) & OR & $95 \% \mathrm{CI}$ \\
\hline Congenital malformations of the nervous system (Q00-Q07) & 1.36 & $1.00-1.86$ \\
\hline Congenital malformations of eye, ear, face, and neck (Q10-Q18) & 1.41 & $0.95-2.10$ \\
\hline Congenital malformations of the circulatory system (Q20-Q28) & $0.78 * * *$ & $0.69-0.89$ \\
\hline Cleft lip and cleft palate (Q35-Q37) & $1.54 * * *$ & $1.17-2.03$ \\
\hline Other congenital malformations of the digestive system (Q38-Q45) & 1.14 & $0.89-1.46$ \\
\hline Congenital malformations of genital organs (Q50-Q56) & 1.12 & $0.91-1.38$ \\
\hline Congenital malformations of the urinary system (Q60-Q64) & $0.59 * * *$ & $0.48-0.72$ \\
\hline Congenital malformations and deformations of the musculoskeletal system (Q65-Q79) & 1.01 & $0.90-1.13$ \\
\hline Other congenital malformations (Q80-Q89) & $1.39 * *$ & $1.16-1.67$ \\
\hline Chromosomal abnormalities, not elsewhere classified (Q90-Q99) & 1.20 & $0.88-1.62$ \\
\hline Congenital malformations of the respiratory system (Q30-Q34) & 1.23 & $0.72-2.10$ \\
\hline
\end{tabular}

$* * P<0.01 ; * * * P<0.001$.

\section{Discussion}

Since the beginning of the 1990s, Latvia has had an unfavorable image among the Central and East European countries that wished to join the European Union. Regarding child mortality and other parameters, Latvia had the worst profile among the Baltic States, even though the socioeconomic situation did not differ much from that of Lithuania and Estonia. The infant mortality indicators came close to those of Rumania and Bulgaria during this period (11).

The UNICEF 2001 report "A Decade of Transition" concluded that Latvia had the highest infant mortality rate in the Baltic States and the highest maternal mortality rate, which was 3 times higher than that of Lithuania or Estonia and exceeded the Rumanian indicator. It also had the highest child mortality (13.6 per 1000 live births) $(2,11)$.

There was a difference in the actual accessibility of health care: almost half of the population could not afford quality pharmaceuticals and/or qualified medical services (13-16). In the late 1990s, 10\% of all the children younger than 5 years lived in extreme poverty and $52.5 \%$ were very poor as compared to corresponding numbers in Lithuania $(4.8 \%$ and $34.7 \%$, respectively). Moreover, this indicator was substantially lower in all the other countries of the region (2). A study by the Norwegian FAFO Institute also reported poor availability of health care in Latvia as compared to Lithuania and Estonia, indicating outstanding differences in health care systems across the Baltic States (17-19).

As evidenced by the correlation/regression equations, there is a rather strong correlation between child mortality in Latvia and health budget. A review of literature shows that this indicator is not always comprehensive. In a number of countries with a relatively high health budget per capita, mortality is higher than in countries that invest in health care by several times less $(4,20)$.
The results of this study show that in Latvia, correlation was strongest between under-five child mortality and health care expenditures per capita (correlation coefficient, 0.74), which means that in 3 of the 4 cases, child mortality was related to health care financing per capita. Prevention of mortality in this age group requires a high amount of investment because of the specific nature of treatment requirements, which frequently involve intensive care.

Since Latvia has the highest child mortality in the EU in practically all age groups apart from those reviewed in the study, it is reasonable to suspect that it might be due to lack of health care financing $(4,21)$. The risks involved are described in the WHO commissioned study "Out of Pocket Health Payments in Households of Latvia and Their Impact on the Capacity to Pay, Analytical Report," Riga 2008 (22). The report analyzes the financial standing of households in 2002-2006 in relation to fairness of health care financing across the country. It shows the affordability of participatory health care payments in different population groups and analyzes fairness of health care financing. Fair distribution of health care costs between the public and the individual is one of the objectives of public health care. Every individual should bear a fair share of health care costs in correspondence to his/her ability to pay, and the remainder of the costs should be borne by the public. For comparability, the WHO speaks about fairness of financial contributions (FFC), i.e., fairness in the distribution of resources. This index reflects the overall inequality caused by differences in the contributions from households with a particular emphasis on the households with high health care costs. In a fair financing system, the index should be close to 1 (23).

In Latvia, the FFC index declined from 0.82 in 2002 to 0.80 in 2005. In 2006, the share of households who could not afford to cover their health 
care contributions was $77 \%$, whereas even during the economic growth period (the so-called "boom years"), there were many households in separate regions of Latvia with catastrophic health care expenditures (as formulated by the WHO); consequently, there is an unequal distribution of the child mortality indicators (20).

The UNICEF study describes the close relationship between unemployment and mortality across different countries and indicates that the correlation coefficient between unemployment and mortality in Latvia in the mid-1990s in particular was 0.78 (2). Our study also revealed a strong correlation between unemployment and under-five child mortality $(r=0.8474)$. The results of the study allow us to conclude that there is a close relationship between child mortality (0-4) and both unemployment and GDP per capita.

The economic crisis has brought about a steep increase in unemployment since 2008, which might reach $20 \%$ in general, whereas in separate regions with unfavorable trends in the natural movement of people, the increase might be even more dramatic, leading to a projected growth in child mortality.

According to the Causes of Death Register of Latvia, congenital anomalies are the second most common cause of infant mortality, which accounts for $25 \%-30 \%$ of infant deaths (5). Since 2000 , there have been no significant increasing or decreasing trends in infant mortality from congenital anomalies, even though infant mortality from congenital anomalies in 2007 was 1.2 times higher ( 2.4 per 1000 live births in 2007 and 1.9 per 1000 in 2006), but in $2008-1.8(24,25)$.

Scientific literature describes a number of epidemiological studies on the relationship of social, demographic, and medical factors with the prevalence of congenital anomalies and mortality $(6-8,26,27)$.

The main socioeconomic factors related to the prevalence of congenital anomalies in newborns reviewed in the present study were maternal education and area of residence (urban or rural).

The prevalence of congenital anomalies in newborns was higher in the urban areas over the period for all diagnostic categories; this might be related to a more polluted environment, occupation and profession of parents (harmful factors at workplace), as well as more synthetic foods used for nutrition. However, the results of the study may be somewhat skewed in view of the fact that the available information may not disclose the real maternal residence area, which may differ from the declared residence address.

In our study, analysis of the structure of anomalies revealed that rate of malformations and deforma- tions of the musculoskeletal system was the highest, followed by malformations of the circulatory system. Contrarily, literature reports a different situation: malformations of the circulatory system rank first, followed by musculoskeletal pathologies (9).

Literature reports data on the interrelation between socioeconomic situation (SES) and neural tube defects, congenital heart conditions, cleft lip in newborns $(7,8)$. A study conducted in the United States included the following factors: maternal and parental education, occupation, and household income (9). Individual SES measures were combined with the overall SES of the household. In household with low SES, the risk was higher for practically all types of congenital defects. The study showed that a higher risk of congenital defects was directly related to household SES, whereas the relationship of individual SES with congenital pathology was less consistent. A lower SES is frequently mentioned as a marker for health outcomes that are generally less favorable. For example, fathers with lower education levels and mothers employed to do menial tasks had a higher risk of having a newborn with cleft palate (OR, 1.4) (9).

The present study demonstrated that, for example, mothers living in the rural area were more likely to have a newborn with cleft lip and cleft palate (OR, 1.54). Notably, maternal and paternal occupation has been left outside the scope of the study, since the data were not available in the database analyzed. In turn, the risk of malformations of the circulatory system $(\mathrm{OR}=1.28)$ and congenital anomalies of the urinary system $(\mathrm{OR}=1.70)$ is higher in urban areas where the social and economic situation is perceived as more favorable, even though there is no information on individual factors.

Literature presents data indicating a higher risk of congenital heart conditions in lower social and economical strata (7). This study did not analyze how the social stratum associated with the newborn was related to congenital anomaly, the focus being on the residence area, which may partly bear relation to social and economic conditions (availability of health care, environmental factors, etc.).

Some studies on the interrelation between social and economic inequality and specific diagnoses of congenital anomalies have been described in literature. A higher prevalence of congenital anomalies in the lower social strata has been noted for congenital cataract, specific circulatory diseases, specific anomalies of the urinary system, polydactyly, syndactyly, etc. $(7,8)$.

A Danish study analyzing the risk of congenital defects in newborns in relationship to parental edu- 
cation and household incomes revealed an impact of these factors on pathology in newborns. Women with a lower education level were at higher risk of having a newborn with congenital anomalies than those with higher education $(\mathrm{OR}=2.9)(7)$.

A more comprehensive interpretation would require a more detailed analysis by territory and in relation to specific environmental factors. The results of the study might be affected to a certain extent by skew factors, such as maternal and paternal occupation, eating habits, harmful environmental factors, a better understanding of which might help to explain the prevalence of congenital anomalies.

\section{Conclusions}

In Latvia, a strong correlation between child mortality and gross domestic product per capita, health care expenditures in LVL per capita, and unemployment level was documented. The period prevalence

\section{References}

1. World Health Organization, Latvia, 2008. WHO. Aug.-Sept. 2008. World Health Organization countries 2005. Available from URL: http://www.who.int/countries/lva/en/

2. UNICEF Innocenti Research Centre. Innocenti Social Monitor 2004. Economic growth and child poverty in the CEE/CIS and the Baltic states. Florence, 2004, ISBN: 8889129-04-2, 22. Available from: URL: http://www.unicefirc. org/publications/pdf/sm2004/sm2004.pdf

3. European health for all databases (HFA-DB). World Health Organization Regional Office for Europe. Updated: January 2007.

4. Ebela I, Bikis E, Rumba-Rozenfelde I. Under-5 child mortality in Latvia: causal relationships and reduction possibilities in an international context. Scientific papers University of Latvia. Vol. 750. Medicine. p. 8-27.

5. Health in the Baltic Countries 2008, 17th ed. 2010; 9-21. Available from: URL: http://vec.gov.lv/uploads/files/4d00 eea89b9b7.pdf

6. Special report: The status of health in the European Union: congenital malformations. June 2009; EUROCAT Central Registry. Available from: URL: http://www.eurocat.ulster. ac.uk

7. Varela MM., Nohr EA, Llopis-González A, Andersen AM, Olsen J. Socio-occupational status and congenital anomalies. Eur J Public Health 2009;19(2):161-7.

8. Vrijheid M, Dolk H, Stone D, Abramsky L, Alberman E, Scott JE. Socioeconomic inequalities in risk of congenital anomaly. Arch Dis Child 2000;82(5):349-52.

9. Yang J, Carmichael SL, Canfield M, Song J, Shaw GM; National Birth Defects Prevention Study. Socioeconomic status in relation to selected birth defects in a large multicentered US case-control study. Am J Epidemiol 2008;167(2): 145-54.

10. Krastiņ̌̌ O, Ciemina I. Statistika, mācību grāmata augstskolām. (Statistics, textbook for universities.) Centrālā statistikas pārvalde; 2008.

11. UNICEF. Innocenti Research Centre. Innocenti Social Monitor 2001. Decade of transition. Florence, 2001, 22. Available from: URL: http://www.unicef-irc.org/publica tions/pdf/monee8/eng/3.pdf

12. LR Veselības ministrija. Mātes un bērna veselības aprūpes stratēgija 2002-2007. (Ministry of Health of the Republic
(2000-2009) for newborns with congenital anomalies according to maternal residence area was higher in urban areas. Mothers residing in rural areas were more likely to have a newborn with cleft lip, cleft palate, and other congenital anomalies, while mothers residing in urban areas were at higher risk of having a newborn with congenital abnormalities of the circulatory and urinary system.

The Latvian government should restructure its health budget providing a higher share of public healthcare finances for covering direct patient costs; unemployment should be reduced and social fairness promoted. It is necessary to analyze causal relationships between child mortality and macroeconomic indicators and health care management in the context of Baltic region regularly.

\section{Statement of Conflict of Interest}

The authors state no conflict of interest.

of Latvia. Healthcare Strategy for Mother and Child 20022007.) Riga: Ministry of Health; 2003. p. 2-8.

13. LU Sociālo un politisko pētījumu institūts. Pārskats par tautas attīstību 2006/2007. (Advanced Social and Political Research Institute at the University of Latvia. Human Development Report 2006/2007.) Riga; 2007. p. 99, 103, 106, 111.

14. Eurochild. Ending child poverty within the EU? A review of the 2006-08 national reports on strategies for social protection and social inclusion. Brussels; 2007. p. 3, 59. Available from: URL: http://www.eurochild.org/fileadmin/ user upload/files/NAPs report 2006 final.pdf

15. Report of Latvian NGO Children's Rights Network to United Nations on Situation of Protection of Children's Rights in Latvia. Compiled by Latvian Save the Children Independent Child's Ombud. Riga; 2006. Available from: URL: http://www.crin.org/docs/NVO Zin en.pdf

16. Alternative Report to the United Nations on the Rights of Children in Latvia 1998-2002. Riga: Latvian Save the Children Independent Child's OMBUD; 2002.

17. Fafo - Report. Better or worse? Living conditions, developments in Estonia, Latvia and Lithuania, 1994-1999. Norway; 2000. p. 32.

18. Fafo - Institute for Applied Social Sciences (Norway). The survey of living conditions in Latvia in 1999. Riga; 2000. p. 118, 124.

19. Latvijas Republikas Centrālā statistikas pārvalde. Dzīves Apstākḷu Apsekojums Latvijā 1999 gadā. (Central Statistical Bureau of Latvia. Overview of Living Conditions in Latvia 1999.) Riga; 2000. p. 118, 124.

20. Ebela I, Karaškēvica J, Rumba-Rozenfelde I. Bērnu mirstība: bērnu slimību riska faktori, cēloņsakarības, novēršanas iespējas. Bērnu slimību riska faktori. LU Akadēmiskais Apgāds. (Child mortality: risk factors, causal relationships, possibilities of prevention. Risk factors in child diseases.) Riga; 2009. p. 141-82.

21. Karaškēvica J, Briğis G̣. Medicīniskās palīdzības pieejamības ietekme uz iedzìvotāju saslimstību un mirstību. Statistikas un pārvaldes problēmas. Zinātniskie raksti. (Effect of healthcare availability on population morbidity and mortality. Statistical and administrative problems. Scientific papers.) Riga: Statistics Institute of Latvia; 2004. p. 82-90). 
22. Out of Pocket Health Payments in households of Latvia and their impact on the capacity to pay. Analytical report. Riga; 2008.

23. The World Health Report 2000: Health systems improving performance. World Health Organization; 2002. p. 1-5, 106.

24. Latvijas veselības aprūpes statistikas gadagrāmata 2007. Veselības statistikas un medicīnas tehnolog̣iju valsts aǵentūra. (Yearbook of health care statistics in Latvia 2008. Health Statistics and Medical Technologies State Agency.) Riga; 2008. p. 17, 43.

25. Latvijas veselības aprūpes statistikas gadagrāmata 2008.

Received 10 May 2011, accepted 29 December 2011
Veselības statistikas un medicīnas tehnolog̣iju valsts ag̊entūra. (Yearbook of health care statistics in Latvia 2009. Health Statistics and Medical Technologies State Agency.) Riga; 2009. p. 45.

26. Abdi-Rad I, Khoshkalam M, Farrokh-Islamlou HR. The prevalence at birth of overt congenital anomalies in Urmia, Northwestern Iran. Arch Iran Med 2008;11(2):148-51.

27. Olesen C, Thrane N, Ronholt AM, Olsen J, Henriksen TB. Association between social position and congenital anomalies: a population-based study among 19,874 Danish women. Scand J Public Health 2009;37(3):246-51. 